DOI:10.18276/sip.2016.46/1-22

\title{
Iwona Foryśs*
}

Uniwersytet Szczeciński

\section{ZMIANY ILOŚCIOWE W SEKTORZE OBSŁUGI RYNKU NIERUCHOMOŚCI - EFEKT DEREGULACJI CZY DEKONIUNKTURY?}

\section{Streszczenie}

Celem artykułu jest analiza zmian na rynku nieruchomości, z uwagi na aktywność podmiotów obsługujących ten rynek. Analizie poddano liczbę podmiotów zarejestrowanych oraz zatrudnionych w systemie REGON w sekcji L PKD 2007. Dla tak określonego zbioru danych analizowano strukturę, współzależność i dynamikę liczby podmiotów, liczby zatrudnionych w sekcji obsługi nieruchomości. W badaniu pozytywnie zweryfikowano hipotezę o wzroście liczby podmiotów obsługujących rynek nieruchomości w efekcie deregulacji zawodów, mimo niekorzystnej koniunktury na tym rynku.

Słowa kluczowe: rynek nieruchomości, deregulacja, dekoniunktura gospodarcza

\section{Wprowadzenie}

Zawody związane z rynkiem nieruchomości rozwinęły się w Polsce wraz ze zmianami ustrojowymi po 90. roku ubiegłego wieku. Gospodarka rynkowa wymagała wykwalifikowanej kadry w segmencie rynku nieruchomości, zwłaszcza w obszarze szacowania wartości rynkowej i zarządzania nieruchomościami (np.

\footnotetext{
*E-mail: forys@wneiz.pl
} 
państwowymi). Rozwój poszczególnych grup zawodowych w pierwszych latach związany był przede wszystkim z powszechną prywatyzacją majątku, począwszy od nieruchomości rolnych Państwowych Gospodarstw Rolnych (PGR), prywatyzacją przedsiębiorstw państwowych, mieszkań komunalnych i zakładowych, po majątek nieprzydatny już krajowi do celów obronnych. Niezbędna była wycena nieruchomości w celu określenia ceny wywoławczej na przetargach, czyli zaangażowanie rzeczoznawcy majątkowego. Pojawiła się zatem konieczność wykształcenia grupy rzeczoznawców majątkowych, którzy takie czynności zgodnie z ustalonymi zasadami mogliby wykonywać. Brak doświadczenia w rynkowym kształtowaniu tego zawodu był przesłanką do uregulowania uprawnień oraz sposobu ich uzyskiwania. Pierwsze uprawnienia rzeczoznawcy majątkowi uzyskali 25 lat temu - jest to najwcześniej wykreowany w Polsce zawód w nowym systemie gospodarczym, bezpośrednio związany z gospodarowaniem nieruchomościami.

Przesuwanie nieruchomości dotychczas niezbywalnych do obrotu rynkowego wywołało konieczność zarządzania nimi (Bryx, 2007), a także profesjonalnej obsługi obrotu w przypadku transakcji coraz bardziej skomplikowanych pod względem prawnym i finansowym (Główka, 2010). Stąd po roku 1990 nastąpił również dynamiczny rozwój zwodów zarządcy nieruchomości i pośrednika w obrocie nieruchomościami, które w 1997 roku również zostały uregulowane aktami prawnymi. W efekcie, wykonywanie każdego z omawianych zawodów wymagało uzyskania stosownych uprawnień zawodowych, nadawanych przez ministra właściwego do spraw budownictwa, po pozytywnym zdaniu egzaminów państwowych. Oznaczało to, że prowadzenie działalności gospodarczej w obszarze kompetencji omawianych zawodów wymagało zatrudnienia osoby mającej odpowiednie uprawniania. Od 1 stycznia 2014 roku nastąpiła deregulacja zawodów pośrednika w obrocie nieruchomościami oraz zarządcy nieruchomości, natomiast uzyskanie uprawnień rzeczoznawcy majątkowego stało się prostsze, gdyż obniżono wymagania szkoleniowe i egzaminacyjne (Jaworski, 2010). Deregulacja w intencji rządu miała znieść bariery dostępu do zawodu i prowadzenia działalności gospodarczej na rynku nieruchomości.

Stąd celem badania jest ocena wpływu deregulacji na aktywność podmiotów gospodarczych w sektorze obsługi rynku nieruchomości, jak również odniesienie omawianego zjawiska do dekoniunktury na rynku nieruchomości w Polsce. Okres badawczy obejmuje lata 2009-2015, czyli okres dekoniunktury na rynku nieruchomości oraz okres przed i po deregulacji omawianych zawodów. W badaniu weryfi- 
kowano hipotezę o wzroście liczby podmiotów obsługujących rynek nieruchomości w efekcie deregulacji zawodów mimo niekorzystnej koniunktury na tym rynku.

W tym celu wykorzystano dane ze statystyki publicznej dotyczącej podmiotów istniejących, nowo zarejestrowanych oraz wyrejestrowanych w systemie REGON w sekcji L - Polskiej Klasyfikacji Działalności Gospodarczej (PKD). Wyniki przeprowadzonych badań mogą służyć decydentom na różnych szczeblach do kształtowania polityki instytucjonalnego rozwoju rynku nieruchomości w Polsce. Do realizacji postawionego celu wykorzystano narzędzia statystyki opisowej.

\section{Obsługa polskiego rynku nieruchomości w systemie prawnym}

Zarządca nieruchomości, pośrednik w obrocie nieruchomościami oraz rzeczoznawca majątkowy są to zawody regulowane na rynku nieruchomości do końca 2013 roku (Foryś, 2009). Zawód regulowany zdefiniowany został dyrektywą 2005/36/WE Parlamentu Europejskiego i Rady z 07.09.2005 roku w sprawie uznawania kwalifikacji zawodowych $i$ jest to

...działalność zawodowa lub zespół działalności zawodowych, których podjęcie, wykonywanie, lub jeden ze sposobów wykonywania wymaga, bezpośrednio bądź pośrednio, na mocy przepisów ustawowych, wykonawczych lub administracyjnych, posiadania specjalnych kwalifikacji zawodowych; w szczególności używanie tytułu zawodowego zastrzeżonego na mocy przepisów ustawowych, wykonawczych i administracyjnych dla osób posiadających odpowiednie kwalifikacje zawodowe stanowi sposób wykonywania działalności zawodowej.

Zgodnie z powyższą dyrektywą kwalifikacje zawodowe poświadczone są dokumentem, który potwierdza kwalifikacje, kompetencje oraz doświadczenie zawodowe. Dokument ten występuje w różnych postaciach i może być wydany jako świadectwo, dyplom lub inny dokument dopuszczony przepisami prawa. W Polsce, aby uzyskać prawo do wykonywania wymienionych czynności na rynku nieruchomości, należało uzyskać licencję (pośrednik i zarządca) oraz uprawniania zawodowe (rzeczoznawca majątkowy). Szczegółowe warunki ich przyznawania określone zostały przepisami Ustawy z 21 sierpnia 1997 roku o gospodarce nieruchomościami i przepisami wykonawczymi do tej ustawy np. Rozporządzeniem Ministra Infrastruktury z 15 lutego 2008 roku w sprawie nadawania uprawnień i licencji zawodowych w dziedzinie gospodarowania nieruchomościami. Zgodnie z pierwotnymi zapisami ustawy, 
uprawnienia nadawano osobie, która w przypadku kandydata na rzeczoznawcę majątkowego miała wyższe wykształcenie, ukończyła studia podyplomowe w zakresie wyceny nieruchomości (lub studia wyższe o specjalności związanej z gospodarką nieruchomościami), odbyła praktykę zawodową w zakresie wyceny nieruchomości oraz przeszła z wynikiem pozytywnym postępowanie kwalifikacyjne, w tym złożyła egzamin dający uprawnienia w zakresie szacowania nieruchomości. Osoby ubiegające się o nadanie licencji pośrednika bądź też zarządcy nieruchomości musiały wykazać się co najmniej średnim wykształceniem, ukończeniem kursu kwalifikacyjnego, odbyciem praktyki zawodowej oraz pozytywnym przejściem przez procedurę egzaminacyjną. Od 1 stycznia 2007 roku kandydat na pośrednika lub zarządcę nieruchomości musiał mieć wykształcenie wyższe i ukończyć studia podyplomowe w zakresie pośrednictwa lub zarządzania nieruchomościami (lub studia o specjalności związanej z gospodarką nieruchomościami).

Wraz ze zmianą przepisów Ustawy o gospodarce nieruchomościami zmieniały się wymagania względem poszczególnych zawodów. Zmiany dotyczyły przede wszystkim sposobu odbywania praktyk oraz przeprowadzania egzaminów i następowały w kilku fazach:

- rzeczoznawca majątkowy: lata 1991-1997, 1998-2013, oraz ostatecznie w 2014 roku - zmniejszenie wymagań szkoleniowych i egzaminacyjnych;

- zarządca nieruchomości: lata 1998-2006, 2007-2008, 2009-2013 (brak egzaminu) oraz 1 stycznia 2014 roku deregulacja zawodu;

- pośrednik w obrocie nieruchomościami: lata 1998-2006, 2007-2008, 2009-2013 (brak egzaminu) oraz 1 stycznia 2014 roku deregulacja zawodu.

Osoby, które uzyskały uprawniania rzeczoznawcy majątkowego, licencję pośrednika $\mathrm{w}$ obrocie nieruchomościami lub licencję zarządcy nieruchomości były wpisywane do Centralnego Rejestru tych zawodów, prowadzonego przez Ministra.

Deregulacja w zawodach nieruchomościowych spowodowała likwidację licencji pośrednika i zarządcy nieruchomości, pozostały (przede wszystkim w innych przepisach) jedynie czynności pośrednictwa i zarządzania. Zniesiono tym samym wymogi dotyczące wykształcenia w obu zawodach, a także odstąpiono od jakiejkolwiek praktyki zawodowej. W przypadku rzeczoznawcy majątkowego skrócono czas odbywania praktyki zawodowej do sześciu miesięcy, zniesiono obowiązek posiadania wykształcenia wyższego na poziomie studiów II stopnia. Ministerstwo 
Sprawiedliwości jako uzasadnienie wniesionych zmian podało przede wszystkim ułatwienie dostępu do wykonywania zawodów związanych z rynkiem nieruchomości dla większej liczby osób (bip.ms.gov.pl). W uzasadnieniu wskazywano, że dobro ekonomiczne powierzane pośrednikom i zarządcom nieruchomości jest chronione nadmiernie, gdyż wystarczającym zabezpieczeniem mogą być obowiązujące przepisy prawa cywilnego oraz ubezpieczenia od odpowiedzialności cywilnej. Jako inne cele deregulacji wskazywano zmniejszenie bezrobocia, a także zwiększenie konkurencji, która powinna prowadzić do podniesienia jakości świadczonych usług oraz do spadku cen usług na rynku nieruchomości.

\section{Podmioty gospodarcze i zatrudnienie w sektorze obsługi rynku nie- ruchomości w okresie dekoniunktury gospodarczej}

Dzięki wykwalifikowanej kadrze rynek nieruchomości powinien ułatwiać obrót nieruchomościami, dostarczać wiarygodnych informacji uczestnikom rynku. Sprawne działanie profesjonalistów na rynkach lokalnych przekłada się na lepszy rozwój gospodarczy kraju. Rynek nieruchomości jest jednym z segmentów gospodarki rynkowej, a same nieruchomości stanowią kapitał, który ma wpływ na tworzenie dodatnich efektów ekonomicznych i ożywienie gospodarcze - udział sektora nieruchomości w PKB szacuje się na poziomie 5\%. Dobrze funkcjonujący rynek nieruchomości ma również wpływ na gospodarkę przez funkcję fiskalną nieruchomości, przepływ kapitałów oraz ludzi (Foryś, 2011).

Działalność związana z zawodami na rynku nieruchomości (wycena, zarządzanie i pośrednictwo) jest zdefiniowana w Polskiej Klasyfikacji Działalności Gospodarczej (PKD 2007) w sekcji L, dziale 68. - działalność związana z obsługą rynku nieruchomości. Czynności trzech zawodów zostały zapisane w podklasie $68.31 . Z$ pośrednictwo w obrocie nieruchomościami, która obejmuje działalność wynajmujących, agentów i/lub maklerów w zakresie: kupna lub sprzedaży nieruchomości, wynajmowania nieruchomości oraz pozostała działalność usługowa związana z nieruchomościami oraz pozostała działalność prowadzona na własnej lub dzierżawionej nieruchomości lub na zlecenie, a także budowa obiektów, na użytek własny lub na wynajem oraz zarządzanie nieruchomościami. W pozostałej działalności znalazły się również czynności, takie jak wycena nieruchomości. Dodatkowo czynności zarządzania zostały sprecyzowane w dwóch podklasach: 68.20.Z oraz 68.32.Z. Ponie- 
waż dostępne dane statystyczne dotyczą całej klasy L oraz działu 68. - działalność związana z obsługą rynku nieruchomości, stąd wobec powyższych rozważań należy uznać, że wszystkie trzy zawody będące przedmiotem analizy zostały zakwalifikowane do tej klasy PKD.

W 2015 roku w omawianej klasie zarejestrowane były 232982 podmioty gospodarcze, podczas gdy w 2009 roku - 185 064. Liczba podmiotów zarejestrowanych w systemie REGON w sekcji L systematycznie (liniowo) wzrasta w latach 2009-2015, mimo trwającej dekoniunktury gospodarczej, przy czym w sektorze publicznym dynamika zmian była niewielka, w latach 2009-2015 zanotowano 5\% wzrost liczby podmiotów istniejących w sekcji L. W przypadku podmiotów prywatnych dynamika zmian była większa, ponieważ wyniosła 30\%. Dodatkowo udział podmiotów prywatnych w sekcji L jest znaczący we wszystkich badanych latach, wyniósł od $76 \%$ w roku 2009 do $80 \%$ w ostatnim roku badania.

Rysunek 1. Wskaźnik liczby ogółem nowo zarejestrowanych podmiotów do istniejących w sekcji L - obsługa nieruchomości w latach 2009-2015

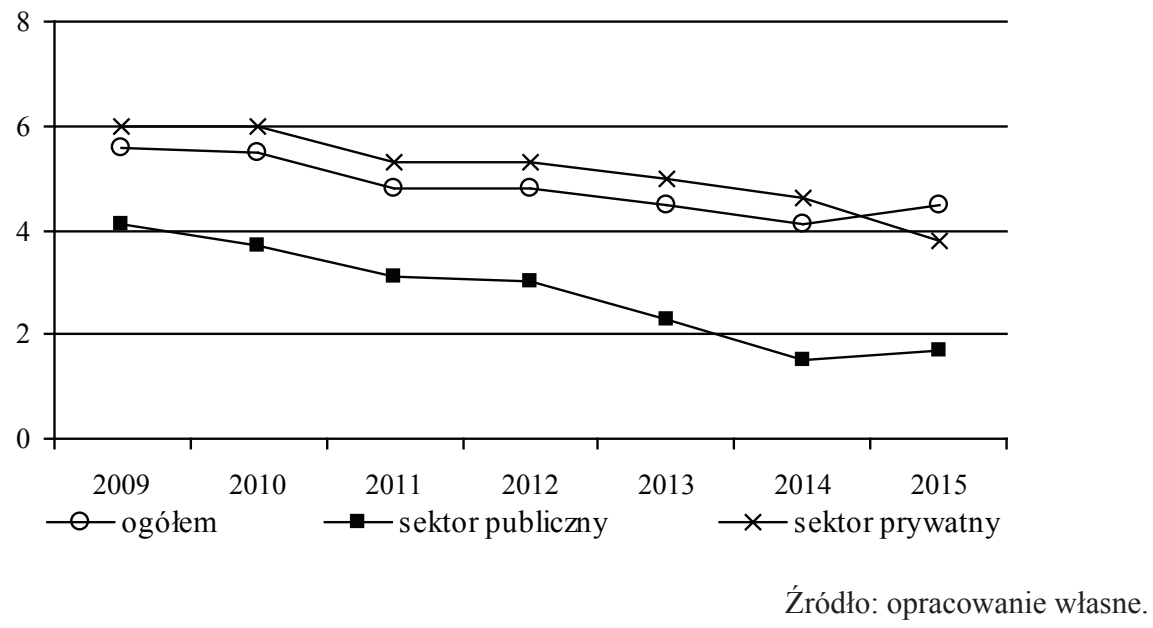

Liczba podmiotów nowo zarejestrowanych w sekcji L w kolejnych badanych latach pozostawała na podobnym poziomie $9-10,7$ tys. podmiotów rocznie, można jednak zauważyć 4\% wzrost w latach 2009-2010, a następnie spadek w 2011 roku o $8,5 \% \mathrm{w}$ stosunku do roku poprzedniego. Kolejny spadek liczby nowo zarejestrowanych podmiotów zauważyć można w 2014 roku, gdy zaczęły obowiązywać nowe 
zasady po deregulacji zawodów. W 2014 roku zarejestrowano najmniej podmiotów w sekcji L w badanym okresie (9 112), zatem jeżeli deregulacja miała wywołać wzrost zainteresowania działalnością gospodarczą w omawianych zawodach, to dopiero w 2015 roku można mówić o reakcji rynku (10 375 nowo zarejestrowanych podmiotów). W przypadku podmiotów nowo rejestrowanych w każdym badanym roku można zauważyć, że podmiotów prywatnych jest dziesięciokrotnie więcej niż podmiotów publicznych. Wskaźnik liczby ogółem nowo zarejestrowanych podmiotów do istniejących w sekcji L w latach 2009-2014 ma tendencję malejącą, natomiast w 2015 roku nastąpiła zmiana tendencji na rosnącą. Relację liczby nowo zarejestrowanych podmiotów do istniejących w sekcji L obsługa nieruchomości z podziałem na podmioty prywatne i publiczne zaprezentowano na rysunku powyżej (rys. 1).

W przypadku podmiotów prywatnych wartość wskaźnika ma tendencję malejącą w całym badanym okresie, zatem deregulacja nie przyniosła oczekiwanych efektów w postaci dynamicznego wzrostu liczy podmiotów w sektorze obsługi nieruchomości. Zmiana tendencji wskaźnika ogółem w 2015 roku wynikała ze zmiany kierunku wskaźnika w sektorze prywatnym. Zmianę aktywności podmiotów do danego sektora pokazuje relacja liczby nowo zarejestrowanych podmiotów do liczby podmiotów wyrejestrowanych w danym roku (rys. 2).

Rysunek 2. Wskaźnik liczby nowo zarejestrowanych podmiotów do wyrejestrowanych w sekcji L - obsługa nieruchomości w latach 2009-2015

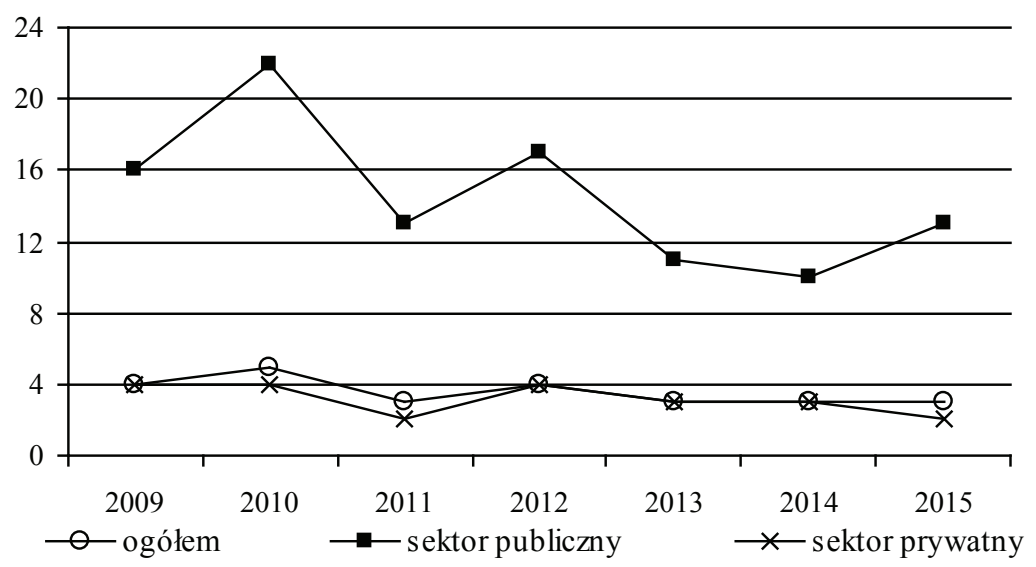

Źródło: opracowanie własne. 
Wskaźnik ten oscyluje wokół czterech, co oznacza, że na każdy podmiot gospodarczy wyrejestrowany $\mathrm{w}$ sekcji L w tym samym roku zostały zarejestrowane cztery nowe. Podobna tendencja miała miejsce w przypadku podmiotów prywatnych, natomiast w przypadku podmiotów publicznych na każdy wyrejestrowany podmiot gospodarczy powstawało od 10 do 22 nowych podmiotów w kolejnych latach, ze stałą tendencją malejącą (rys. 2). Przy czym w każdym rodzaju własności podmiotów gospodarczych można mówić o stałej tendencji wskaźnika w badanych latach dekoniunktury gospodarczej oraz braku istotnych zmian wartości wskaźnika od 2014 roku, gdy zaczęła obowiązywać deregulacja zawodów nieruchomościowych.

Wskaźnik liczby podmiotów wyrejestrowanych do istniejących ma tendencję rosnącą (z wahaniem w 2011 roku) z wyjątkiem sektora publicznego (rys. 3). W tym przypadku można potwierdzić, że tendencja wyrejestrowywania podmiotów jest zgodna z utrzymującą się dekoniunkturą na rynku nieruchomości i w gospodarce, natomiast nie ma wyraźnego związku z ułatwieniem dostępu do omawianych trzech zawodów nieruchomościowych.

Rysunek 3. Wskaźnik liczby wyrejestrowanych firm do istniejących w sekcji L - obsługa nieruchomości w latach 2009-2015

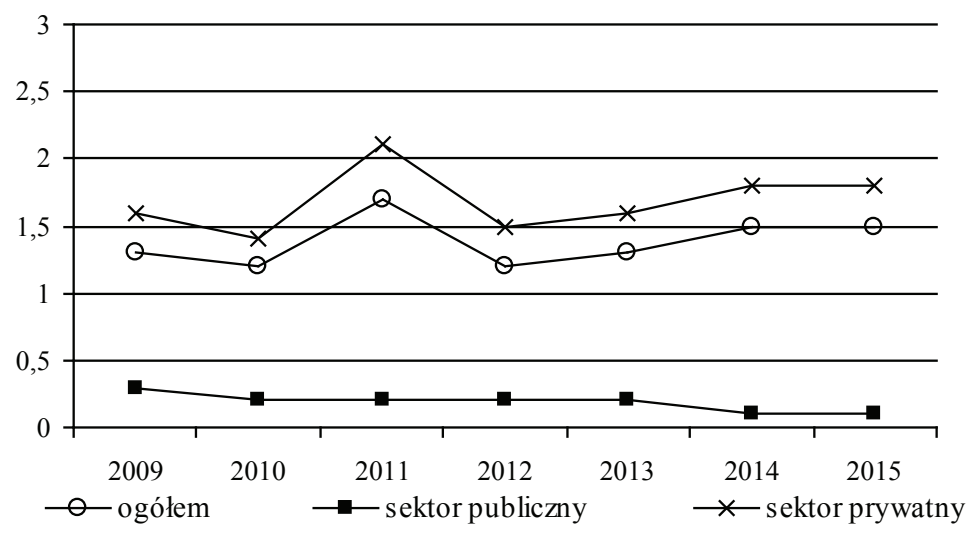

Źródło: opracowanie własne.

Badanie tendencje na rynku podmiotów obsługujących rynek nieruchomości uzupełniono analizą zatrudnienia w sektorze L. W 2009 roku w badanym sektorze zatrudnieniowych było 190,3 tys. osób , w 2014 roku 202,4 tys. osób. W badanym 
okresie nastąpił zatemdynamiczny $(6,3 \%)$ wzrost liczby zatrudnionych, z załamaniem w 2012 roku, gdy zatrudnienie w sektorze wyniosło 193,7 tys. osób (rys. 4).

Rysunek 4. Dynamika liczby zatrudnionych w sekcji L

- obsługa nieruchomości w latach 2009-2014 (tys.)

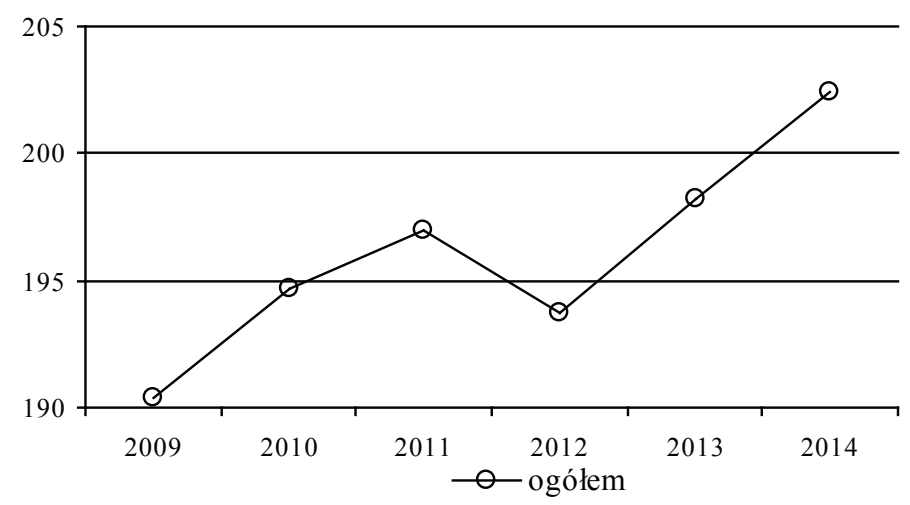

Źródło: opracowanie własne.

Zależność między liczbą zatrudnionych a liczbą podmiotów gospodarczych zarejestrowanych w PKD sekcja L jest wysoka i dodatnia, w analizowanym okresie współczynnik korelacji Pearsona wyniósł 0,871. W latach 2009-2014 zależność między liczbą podmiotów istniejących a nowo rejestrowanych jest wysoka i ujemna $(-0,775)$, a wyrejestrowanych dodatnia $(0,576)$. Podobnie ujemna korelacja jest między liczbą podmiotów wyrejestrowanych a nowo zarejestrowanych $(-0,854)$, natomiast dodatnia $\mathrm{w}$ odniesieniu do zatrudnienia $(0,730)$. Zatrudnienie jest ujemnie skorelowane z liczbą wyrejestrowanych podmiotów $(-0,829)$.

\section{Przestrzenne zróżnicowanie wg województw aktywności podmio- tów sekcji L - obsługa rynku nieruchomości}

Przestrzenną aktywność podmiotów obsługujących rynek nieruchomości analizowano w układzie województw. Badaniu podlegała dynamika zatrudnienia w sektorze w latach 2009-2014 (brak danych w GUS za 2015 rok), a także dynamika licz- 
by istniejących podmiotów gospodarczych w sekcji L oraz nowo zarejestrowanych i wyrejestrowanych w latach 2009-2015.

Średnio w województwach w 2009 roku zarejestrowanych było 11,6 tys. podmiotów gospodarczych, podczas gdy w 2015 roku już 14,6 tys. W połowie województw liczba podmiotów w rejestrze wyniosła 9-11 tys., przy czym najwięcej podmiotów w tej sekcji było w województwie dolnośląskim (39,9 tys. w 2015 roku) oraz mazowieckim (32,2 tys. w 2015 roku). Województwa są bardzo zróżnicowane z uwagi na badaną liczbę istniejących podmiotów i stan taki utrzymuje się w całym analizowany okresie, na co wskazuje zarówno współczynnik zmienności jak i skośność (tab. 1).

Tabela 1. Statystyki opisowe liczby istniejących podmiotów gospodarczych w sekcji L w latach 2009-2015

\begin{tabular}{|l|r|r|r|r|r|r|r|}
\hline Ogółem istniejące & 2009 & 2010 & 2011 & 2012 & 2013 & 2014 & 2015 \\
\hline Średnia & 11567 & 12212 & 12667 & 13162 & 13634 & 14043 & 14560 \\
\hline Mediana & 9161 & 9435 & 9776 & 10390 & 10661 & 10864 & 11054 \\
\hline Minimum & 2139 & 2344 & 2460 & 2610 & 2807 & 2919 & 3068 \\
\hline Maksimum & 32474 & 34214 & 35424 & 36516 & 37856 & 38683 & 39974 \\
\hline Kwartyl dolny & 5651 & 5991 & 6250 & 6449 & 6591 & 6744 & 6935 \\
\hline Kwartyl górny & 15243 & 15973 & 16489 & 16958 & 17410 & 17932 & 18724 \\
\hline $\begin{array}{l}\text { Odchylenie stan- } \\
\text { dardowe }\end{array}$ & 8581 & 9083 & 9403 & 9705 & 10117 & 10401 & 10836 \\
\hline $\begin{array}{l}\text { Współczynnik } \\
\text { zmienności }\end{array}$ & 74,19 & 74,38 & 74,24 & 73,74 & 74,21 & 74,07 & 74,43 \\
\hline Skośność & 1,21 & 1,22 & 1,22 & 1,20 & 1,22 & 1,20 & 1,21 \\
\hline Kurtoza & 1,05 & 1,02 & 1,01 & 0,97 & 0,97 & 0,90 & 0,88 \\
\hline
\end{tabular}

Źródło: obliczenia własne.

Jeszcze większe zróżnicowanie województw widoczne jest w liczbie podmiotów nowo zarejestrowanych (tab. 2), na co wskazuje zarówno wysoki i rosnący współczynnik zmienności, jak również współczynnik skośności. Średnio rocznie rejestrowano od 69 do 668 podmiotów, przy tendencji malejącej do 2014 roku 
i wzroście w 2015 roku. Najmniej podmiotów zarejestrowano w województwie podkarpackim i opolskim - niemal dziewięciokrotnie mniej niż w województwie mazowieckim.

Tabela 2. Statystyki opisowe liczby nowo zarejestrowanych podmiotów gospodarczych w sekcji L w latach 2009-2015

\begin{tabular}{|l|r|r|r|r|r|r|r|}
\hline \multicolumn{1}{|c|}{ Statystyki opisowe } & 2009 & 2010 & 2011 & 2012 & 2013 & 2014 & 2015 \\
\hline Średnia & 643 & 668 & 611 & 636 & 613 & 569 & 648 \\
\hline Mediana & 517 & 405 & 447 & 518 & 358 & 392 & 408 \\
\hline Minimum & 122 & 167 & 117 & 118 & 108 & 98 & 138 \\
\hline Maksimum & 1755 & 1874 & 1759 & 1834 & 2117 & 1982 & 2319 \\
\hline Kwartyl dolny & 224 & 264 & 235 & 253 & 239 & 222 & 236 \\
\hline Kwartyl górny & 854 & 896 & 805 & 934 & 837 & 847 & 941 \\
\hline Odchylenie standardowe & 486,4 & 551,8 & 477,1 & 466,6 & 559,7 & 492,1 & 593,8 \\
\hline Współczynnik zmienności & 75,6 & 82,6 & 78,0 & 73,3 & 91,3 & 86,4 & 91,6 \\
\hline Skośność & 1,16 & 1,33 & 1,30 & 1,18 & 1,68 & 1,72 & 1,71 \\
\hline Kurtoza & 0,81 & 0,96 & 1,13 & 1,43 & 2,55 & 3,51 & 3,10 \\
\hline
\end{tabular}

Źródło: obliczenia własne.

W przypadku podmiotów wyrejestrowanych, najwyższe zróżnicowanie województw wystąpiło w 2011 oraz 2014 roku, co jednak nie mało związku z deregulacją (tab. 3). Najwięcej podmiotów wyrejestrowywano w województwach mazowieckim i śląskim, najmniej w podlaskim, opolskim i podkarpackim.

Tabela 3. Statystyki opisowe liczby wyrejestrowanych podmiotów gospodarczych w sekcji L w latach 2009-2015

\begin{tabular}{|l|r|r|r|r|r|r|r|}
\hline \multicolumn{1}{|c|}{ Statystyki opisowe } & 2009 & 2010 & \multicolumn{1}{c|}{2011} & \multicolumn{1}{c|}{2012} & 2013 & 2014 & 2015 \\
\hline \multicolumn{1}{|c|}{1} & \multicolumn{1}{c|}{2} & \multicolumn{1}{c|}{3} & \multicolumn{1}{c|}{4} & \multicolumn{1}{c|}{5} & \multicolumn{1}{c|}{6} & 7 & 8 \\
\hline Średnia & 150 & 141 & 219 & 163 & 176 & 209 & 215 \\
\hline Mediana & 123 & 116 & 171 & 112 & 133 & 146 & 142 \\
\hline Minimum & 31 & 30 & 51 & 41 & 38 & 49 & 60 \\
\hline
\end{tabular}




\begin{tabular}{|l|r|r|r|r|r|r|r|}
\hline \multicolumn{1}{|c|}{1} & \multicolumn{1}{c|}{2} & \multicolumn{1}{c|}{3} & \multicolumn{1}{c|}{4} & \multicolumn{1}{c|}{5} & \multicolumn{1}{c|}{6} & \multicolumn{1}{c|}{7} & \multicolumn{1}{c|}{8} \\
\hline Maksimum & 569 & 504 & 989 & 657 & 651 & 909 & 897 \\
\hline Kwartyl dolny & 57 & 58 & 79 & 59 & 68 & 75 & 81 \\
\hline Kwartyl górny & 215 & 177 & 270 & 202 & 240 & 258 & 274 \\
\hline $\begin{array}{l}\text { Odchylenie } \\
\text { standardowe }\end{array}$ & 132,5 & 117,7 & 227,8 & 153,2 & 158,1 & 214,4 & 210,2 \\
\hline $\begin{array}{l}\text { Współczynnik } \\
\text { zmienności }\end{array}$ & 88,31 & 83,63 & 104,25 & 94,28 & 89,61 & 102,57 & 97,87 \\
\hline Skośność & 2,27 & 2,14 & 2,83 & 2,46 & 1,99 & 2,57 & 2,52 \\
\hline Kurtoza & 6,49 & 5,68 & 9,48 & 7,34 & 4,81 & 7,83 & 7,57 \\
\hline
\end{tabular}

Źródło: obliczenia własne.

Współczynnik liczby podmiotów nowych do wyrejestrowanych był najwyższy w województwie dolnośląskim, gdzie w latach 2009-2010 w miejsce jednego wyrejestrowanego było rejestrowanych nawet 8 lub 9 podmiotów. Najmniejszą wartość analizowany współczynnik uzyskał w województwie świętokrzyskim - w całym badanym okresie w sekcji obsługi nieruchomości dwa lub trzy podmioty nowe powstawały w miejsce każdego podmiotu wyrejestrowanego. W latach 2014-2015, po deregulacji, w większości województw współczynnik przyjmował wartości na poziomie dwóch lub trzech i w konkretnych województwach był często kilkakrotnie niższy niż w pozostałych latach.

Analiza zatrudnienia w sektorze obsługi nieruchomości wskazuje na ogólna tendencję spadkową w większości województw w badanych latach (tab. 4). Największy spadek zatrudnienia w stosunku do 2009 roku nastąpił w województwach dolnośląskim, opolskim i kujawsko-pomorskim, co może być jednak powodem zmian w strukturze zatrudnienia podmiotów działających na rynku nieruchomości np. w kierunku podmiotów jednoosobowych. Najbardziej stabilne w zatrudnieniu okazało się województwo podlaskie, natomiast lubuskie i zachodniopomorskie cechował wzrost zatrudnienia w sektorze na przestrzeni badanych lat. Podobnie jak w przypadku analizy liczby podmiotów gospodarczych, również w przypadku zatrudnienia w sektorze obsługi nieruchomości widoczne jest zróżnicowanie przestrzenne oraz niekorzystna tendencja związana z dekoniunkturą na rynku nieruchomości. 
Tabela 4. Dynamika zatrudnienia ogółem w sekcji L wg województw w latach 2010-2014 (2009 = 100)

\begin{tabular}{|l|c|c|c|c|c|}
\hline \multicolumn{1}{|c|}{ Województwo } & 2010 & 2011 & 2012 & 2013 & 2014 \\
\hline lódzkie & 95 & 97 & 98 & 100 & 93 \\
\hline mazowieckie & 99 & 98 & 99 & 96 & 94 \\
\hline małopolskie & 94 & 99 & 98 & 93 & 89 \\
\hline śląskie & 98 & 98 & 99 & 96 & 96 \\
\hline lubelskie & 96 & 94 & 100 & 97 & 96 \\
\hline podkarpackie & 97 & 95 & 100 & 97 & 98 \\
\hline podlaskie & 100 & 97 & 102 & 100 & 100 \\
\hline świętokrzyskie & 104 & 96 & 103 & 97 & 100 \\
\hline lubuskie & 100 & 103 & 107 & 108 & 104 \\
\hline wielkopolskie & 103 & 101 & 101 & 97 & 94 \\
\hline zachodniopomorskie & 99 & 103 & 111 & 109 & 106 \\
\hline dolnośląskie & 96 & 91 & 91 & 88 & 87 \\
\hline opolskie & 96 & 97 & 98 & 89 & 87 \\
\hline kujawsko-pomorskie & 95 & 93 & 92 & 89 & 87 \\
\hline pomorskie & 96 & 88 & 92 & 97 & 95 \\
\hline warmińsko-mazurskie & 96 & 95 & 99 & 98 & 97 \\
\hline
\end{tabular}

Źródło: obliczenia własne.

Zależność między liczbą zatrudnionych a liczbą podmiotów gospodarczych zarejestrowanych w PKD - sekcja L w ujęciu przestrzennym jest wysoka i dodatnia. W analizowanych latach i badanych województwach współczynnik korelacji Pearsona wyniósł odpowiednio: 0,68 w 2009 roku, $0,70 \mathrm{w} 2010$ roku, 0,71 w latach 2011 i 2012 oraz 0,72 w roku 2013, zaś najwyższy - 0,73 - w 2014 roku. Oznacza to, że wraz ze wzrostem zatrudnienia w sektorze rośnie liczba podmiotów gospodarczych tego sektora, niezależnie od niekorzystnej fazy cyklu koniunkturalnego na rynku nieruchomości i cyklu gospodarczego. 


\section{Wnioski}

Do końca 2013 roku zawody rzeczoznawcy majątkowego, pośrednika w obrocie nieruchomościami oraz zarządcy nieruchomości były w Polsce regulowane. Założeniem deregulacji tych zawodów było ich otwarcie na nowe podmioty, a co za tym idzie - zwiększenie zainteresowania profesjonalną obsługą rynku nieruchomości. Proponowane zmiany zbiegły się z trwającą od połowy 2008 roku dekoniunkturą na rynku nieruchomości (Foryś, 2009). Założenie, że w wyniku deregulacji nastąpi znaczący wzrost zatrudnienia oraz aktywności nowo powstających podmiotów obsługi rynku nieruchomości okazało się błędne. $Z$ przeprowadzonych analiz wynika raczej, że zjawiska które miały miejsce na polskim rynku w sektorze obsługi tego rynku są ściśle związane z dekoniunkturą gospodarczą, a nie ingerencją państwa W regulowanie instytucjonalnego otoczenia rynku nieruchomości. W ciągu dwóch lat po deregulacji nie można zauważyć wprost dynamicznego wzrostu podmiotów zainteresowanych prowadzeniem działalności w obszarze zarządzania czy pośrednictwa na rynku nieruchomości, podobnie jak wzrostu zatrudnienia w tym sektorze. Niewielki wzrost zarejestrowanych nowych podmiotów jest zauważalny dopiero w 2015 roku, co wiąże się raczej z poprawą koniunktury na rynku, a nie deregulacją.

Można więc uznać, że w okresie dekoniunktury nie da się wykazać pozytywnych efektów ilościowych zakładanych w uzasadnieniu deregulacji zawodów rynku nieruchomości, zatem przeprowadzony proces był przedwczesny lub wręcz zbędny.

\section{Literatura}

Bryx, M. (red.) (2007). Wprowadzenie do zarzadzania nieruchomościami. Warszawa: Wydawnictwo Poltex.

Dyrektywa 2005/36/WE Parlamentu Europejskiego i Rady z 7 września 2005 w sprawie uznawania kwalifikacji zawodowych. Pobrano z http://eur-lex.europa.eu/legal-content/ $\mathrm{PL} / \mathrm{TXT} /$ ?uri=celex\%3A32005L0036.

Foryś, I. (red.) (2009). Obrót nieruchomościami. Warszawa: Wydawnictwo Poltext.

Foryś, I. (2011). Spoteczno-gospodarcze determinanty rozwoju rynku mieszkaniowego w Polsce. Szczecin: Wydawnictwo Naukowe Uniwersytetu Szczecińskiego.

Główka, G. (2010). Mieszkaniowy kredyt hipoteczny w Polsce. Warszawa: Oficyna Wydawnicza SGH. 
Jaworski, J. (2010). Reglamentacja zawodów rynku nieruchomości. Warszawa: Wydawnictwo C.H.Beck.

Rozporządzenie Rady Ministrów z 24 grudnia 2007 r. w sprawie Polskiej Klasyfikacji Działalności (PKD), Dz.U. 2007 nr 251 poz. 1885.

Rozporządzenie Ministra Infrastruktury z 15 lutego 2008 roku w sprawie nadawania uprawnień i licencji zawodowych w dziedzinie gospodarowania nieruchomościami (Dz.U. 2008 nr 31 poz. 189).

Ustawa z 21 sierpnia 1997 r. o gospodarce nieruchomościami (Dz. U. z 2015 r. poz. 782 $\mathrm{z} \mathrm{zm}$.).

https://bip.ms.gov.pl/pl/projekty-aktow-prawnych/pozostale/download,1946,1.html (04.06.2016).

\section{QUANTITATIVE CHANGES IN THE REAL ESTATE MANAGEMENT SECTOR - THE EFFECT OF DEREGULATION OR OF RECESSION?}

\section{Summary}

The aim of this article is to analyze the changes on the real estate market taking into consideration the activeness of the entities managing this market. The number of entities registered and employed in the REGON system in the L section of the PKD 2007 was subject to the analysis. In the data set determined as such, the structure, interrelation, and the dynamics of the number of entities, the number of those employed in the real estate market management section were analyzed. The results were related to the number of professional entitlements and licensing obtained. The hypothesis on the increase in the entities managing real estate market as a consequence of the professions deregulation, despite the adverse prosperity, was positively verified.

Keywords: real estate market, deregulation, economic recession

Kody JEL: C21, C43, R21, R31 
